\title{
Effects of heat-treated J ack beans on the performance characteristics and hematology profile in the commercial broiler
}

\author{
AM Akanji*, AM Ogungbesan \\ Department of Animal Production, College of Agricultural Sciences, Olabisi Onabanjo University, Yewa \\ Campus, Ayetoro, Ogun State, Nigeria
}

\begin{abstract}
A study was carried out to assess the effects of aqueous-heated and dry-heated Jack beans on the growth, hematology, serum metabolites and enzymes of broiler chickens. Jack beans were processed by aqueous heating into two different batches. In the first batch of aqueous-heated Jack beans (AHJ B1), raw seeds were soaked in distilled water for $48 \mathrm{hrs}$ prior to cooking in fresh water for $1 \mathrm{hr}$ The second batch (AHJB2) had raw Jack beans soaked in distilled water for $48 \mathrm{hrs}$ prior to $2 \mathrm{hrs}$ cooking at $1 \mathrm{hr}$ interval. In preparing the dry-heated Jack beans (DHJ), the raw seeds were roasted in an oven at $120^{\circ} \mathrm{C}$ for 30 minutes. Four hundred and twenty (420) broiler chicks of ANAK strain were randomly allotted to seven dietary groups. The aqueous - heated and dry-heated Jack beans were incorporated in to the diets at $15 \%$ and $30 \%$ levels respectively. Higher residual amounts of canavanine, trypsin inhibitor and haemagglutinin were retained in DHJB. The Performance characteristics showed significant $(P<0.05)$ reductions in feed intake, body weight gain and feed conversion efficiency of birds fed $15 \%$ and $30 \% \mathrm{AHJB1}$ and $\mathrm{DHJB}$, and 30\% $\mathrm{AHJB2}$, respectively. Blood studies revealed marked reductions $(P<0.05)$ in red blood cells, packed cell volume and hemoglobin of birds fed $D H J B$ diets. Over all, the best significant improvements in the response indices were obtained in birds fed $15 \%$ AHJ B2 as the birds fed on the diet compared favorably with the control group.
\end{abstract}

Key words: Jack beans, processing, broilers, response indices

Bangladesh Animal Husbandry Association. All rights reserved. Bang. J. Anim. Sci. 2014.43 (3): $207-212$

\section{Introduction}

Jack bean (Canavalia ensiformis) is a tropical leguminous plant with a high yield of seeds and foliage (Eke et al. 2007). According to Sridha (2005), the seed of the Jack bean is a relatively good source of protein and apparent metabolizable energy for the young chicks. However, raw Jack bean contains some toxic compounds such as canavanine, concanavalin A (haemagglutinin), tannin, saponins, oxalate, phytate and trypsin inhibitors which have been reported to cause negative effect on the growth of rats and chickens (Udedibie and Carlini, 1998). Prominent among the anti-nutritional factors in Jack beans are the trypsin inhibitors which inhibit digestive enzymes, the haemagglutinins or lectins which adversely affect the absorption of nutrients from the intestinal tracts and canavanine which forms a complex interaction and antagonism with arginine in poultry.
Attempts to upgrade the seed of Jack bean for monogastric animals have focused principally on the detoxification of canavanine and Concanavalin A (haemagglutinin), since together or in isolation these anti-nutritional factors exert profound appetite and growth-depressing effects particularly in avian species (D'Mello et al, 1989; Leon et al, 1991). While concanavanine A (haemagglutinin) in Jack bean gets destroyed under moist heating, canavanine remains stable at dry heat temperature of $184^{\circ} \mathrm{C}$ (Ologhobo et al. 1993).

Hence, this study was carried out to look at the effects of modified aqueous heating and dry heating methods, at eliminating the anti nutritional factors in Jack beans. The second objective of this study was to look at the effects of the aqueous-heated and dry-heated Jack beans on performance characteristics and hematological indices of broiler chickens. 


\section{Utilization of processed Jack beans in broiler diet}

\section{Material and Method}

This study was carried out at the Teaching and Research Farm of the University of Ibadan, South West of Nigeria. Raw Jack bean seeds were acquired from the National Cereals and Research Institute, Ibadan, South West of Nigeria. The seeds were processed using aqueous heating and dry heating respectively.

Raw Jack bean seeds were subjected to aqueous heating according to the method described by Obizoba and Obiano (1998) and Ologhobo et al. (1993) with slight modifications. The first batch of raw Jack beans was completely immersed in distilled water for $48 \mathrm{hrs}$ at room temperature $\left(26^{\circ} \mathrm{C}\right)$ and then cooked in fresh distilled water ( $250 \mathrm{~g} \mathrm{seed} / \mathrm{l})$ for $1 \mathrm{hr}$. Both the soaking and cooking water extracts were discarded. The cooked seeds were oven-dried at $40^{\circ} \mathrm{C}$ and ground in a Moulinex coffee grinder. This batch of aqueous-heated Jack bean seeds was labeled AHJ B1.

Another batch of raw Jack beans was also soaked in fresh distilled water for $48 \mathrm{hrs}$ at room temperature $\left(26^{\circ} \mathrm{C}\right)$. Moreover, after the soaking, the seeds were cooked in fresh distilled water $(250 \mathrm{~g} \mathrm{seed} / \mathrm{l})$ for $2 \mathrm{hrs}$ at $1 \mathrm{hr}$ interval. After the first $1 \mathrm{hr}$ of cooking, the water extract was discarded and the Jack beans cooked in another fresh distilled water ( $250 \mathrm{~g}$ seed/L) for another $1 \mathrm{hr}$. The cooked Jack beans were then oven dried at $40^{\circ} \mathrm{C}$ and ground in a Moulinex coffee grinder. This batch of aqueous- heated Jack bean seeds was labeled AHJ B2. Dry Jack bean seeds were subjected to dry heating in an oven at $120^{\circ} \mathrm{C}$ for 30 minutes. The dry heating was considered adequate when the seeds changed colour from white to brown and became crispy to touch. This batch of dry-heated Jack bean seeds was labeled DHJB. Proximate composition of the raw, aqueous-heated and dry-heated Jack beans were analyzed by the analytical procedures of AOAC (1984). Trypsin inhibitor, haemagglutinin and canavanine contents were determined by the methods described by Van Oort et al. (1989) Valdebouze et al. (1980) and Natelson and Bratton (1994) respectively.

A total of seven starter broiler diets were formulated. One of the diets was basal, while the remaining six diets either contained aqueous or dry heated at $15 \%$ and $30 \%$ levels respectively. A total of 420 one-day-old broiler chicks of Anak strain (commercial broiler strain in Nigeria) were purchased from a commercial hatchery and housed in electrically heated battery brooder with raised screed floors. The chicks were randomly assigned to seven groups at 60 chicks per group. Each group was replicated three times with 20 chicks per replication. Feed and water were provided ad libitum. The house, feeding equipment and drinkers were thoroughly washed and disinfected prior to the arrival of the day old chicks. The birds were vaccinated against Newcastle disease on the $28^{\text {th }}$ day and gumboro (infectious bursal disease) on the $10^{\text {th }}$ and $35^{\text {th }}$ day respectively. The experiment was terminated at the end of the fifth week of age of birds.

Table 1. Composition of feed ingredients of starter diets for broilers

\begin{tabular}{|c|c|c|c|c|c|c|c|}
\hline & Control & 15\% AHJB1 & $30 \%$ AHJB1 & 15\% AHJB2 & $30 \%$ AHJB2 & $15 \% \mathrm{DHJB}$ & $30 \% \mathrm{DHJB}$ \\
\hline Maize & 56.80 & 54.55 & 51.55 & 52.95 & 50.40 & 55.40 & 51.85 \\
\hline Soybean & 30.00 & 17.00 & 4.00 & 18.00 & 5.00 & 16.00 & 4.50 \\
\hline Jack bean & - & 15.00 & 30.00 & 15.00 & 30.00 & 15.00 & 30.00 \\
\hline Fish meal & 4.30 & 6.30 & 7.40 & 6.80 & 7.30 & 6.10 & 6.60 \\
\hline Brewers dried grain & 2.50 & 0.75 & 0.65 & 0.85 & 0.90 & 1.10 & 0.65 \\
\hline Blood meal & 3.00 & 3.00 & 3.00 & 3.00 & 3.00 & 3.00 & 3.00 \\
\hline Bone meal & 2.50 & 2.50 & 2.50 & 2.50 & 2.50 & 2.50 & 2.50 \\
\hline Salt & 0.25 & 0.25 & 0.25 & 0.25 & 0.25 & 0.25 & 0.25 \\
\hline Premix & 0.50 & 0.50 & 0.50 & 0.50 & 0.50 & 0.50 & 0.50 \\
\hline Methionine & 0.15 & 0.15 & 0.15 & 0.15 & 0.15 & 0.15 & 0.15 \\
\hline Calculated crude protein(\%) & 23.2 & 22.50 & 22.61 & 23.10 & 22.34 & 22.90 & 22.30 \\
\hline Calculated metabolizable energy(MJ) & 12.12 & 11.90 & 11.74 & 11.83 & 12.21 & 11.85 & 11.79 \\
\hline
\end{tabular}

AHJB1, aqueous-heated Jack beans (beans soaked in distilled water for $48 \mathrm{hrs}$ prior to $1 \mathrm{hr}$ cooking at $100{ }^{\circ} \mathrm{C}$ ); AHJB2, aqueous-heated Jack beans (beans soaked in distilled water for 48 hrs prior to 2 hrs cooking at $1 \mathrm{hr}$ interval); DHJB, dry-heated Jack beans (beans oven-dried at $120^{\circ} \mathrm{C}$ for $30 \mathrm{~min}$.) 
On the $28^{\text {th }}$ day of the experiment, blood samples were collected from six (6) live birds per treatment (2 from each replicate group) from brachial vein through the use of syringe with needle into tubes containing ethylene diamine tetra-acetic dipotassium salt (EDTA) for hematological examination, and in ice cooled centrifuge tubes for enzyme assay and metabolic analysis. Hematological indices such as red blood cells ( $\mathrm{RBC}$ ), hemoglobin ( $\mathrm{Hb})$, packed cell volume (PCV) and white blood cells (WBC) were determined by procedures outlined by Dacie and Lewis (1977). The data were analyzed by analysis of variance. Where significant treatment effects were obtained, their means were compared using Duncan Multiple Range Test (Steel and Torrie 1980).

\section{Results}

The proximate composition of the raw, aqueousheated and dry-heated Jack bean seeds are shown in Table 2. Marginal variations between the aqueous-heated and dry-heated Jack bean for crude protein, fiber, fat, ash and carbohydrates were observed. Crude protein was slightly increased in the DHJB, but reduced in $A H J B 1$ and $A H J B 2$ respectively.

Table 2. Proximate composition of raw, aqueous-heated and dry-heated Jack beans (expressed as percentage dry matter)

\begin{tabular}{lcccccc}
\hline $\begin{array}{l}\text { Jack } \\
\text { beans }\end{array}$ & $\begin{array}{c}\text { Crude } \\
\text { protein }\end{array}$ & $\begin{array}{c}\text { Crude } \\
\text { fiber }\end{array}$ & Fat & Ash & NFE & $\begin{array}{c}\text { Dry } \\
\text { matter }\end{array}$ \\
\hline RJB & 28.2 & 9.4 & 2.4 & 3.5 & 51.8 & 95.3 \\
AHJB1 & 27.1 & 9.2 & 2.1 & 3.2 & 52.2 & 93.8 \\
AHJB2 & 26.6 & 8.9 & 2.0 & 3.1 & 52.8 & 93.4 \\
DHJB & 29.9 & 9.7 & 2.4 & 3.6 & 50.8 & 96.4 \\
\hline
\end{tabular}

RJB, raw Jack beans; NFE, nitrogen free extract; AHJB1, aqueousheated Jack beans (beans soaked in distilled water for 48 hrs prior to $1 \mathrm{hr}$ cooking at $100^{\circ} \mathrm{C}$ ); AHJB2, aqueous-heated Jack beans (beans soaked in distilled water for $48 \mathrm{hrs}$ prior to $2 \mathrm{hrs}$ cooking at $1 \mathrm{hr}$ interval); $D H J B$, dry-heated Jack beans (beans oven-dried at $120^{\circ} \mathrm{C}$ for $30 \mathrm{~min}$.)

Data on the anti-nutritional factors are presented in Table 3. High concentrations of canavanine, haemagglutinin and trypsin inhibitors were obtained in the raw Jack beans. Residual amount of canavanine was more in DHJB, while AHJB2 contained the least amount of the anti nutritional factor. Further, higher amounts of haemagglutinin and trypsin inhibitors were retained in DHJB, but completely destroyed in AHJB1 and AHJB2.

Table 3. Anti-nutritional factors in raw and aqueous-heated and dry-heated Jack beans

\begin{tabular}{lllllll}
\hline $\begin{array}{l}\text { Jack } \\
\text { beans }\end{array}$ & $\begin{array}{l}\text { CAN } \\
(\mathrm{mg} / \mathrm{g})\end{array}$ & $\begin{array}{l}\text { \% loss } \\
\text { in CAN }\end{array}$ & $\begin{array}{l}\mathrm{Hg} \\
\text { (g/seed) }\end{array}$ & $\begin{array}{l}\text { \% loss } \\
\text { in Hg }\end{array}$ & $\begin{array}{l}\mathrm{TI} \\
\text { (g/seed) }\end{array}$ & $\begin{array}{l}\text { \% loss } \\
\text { in TI }\end{array}$ \\
\hline RJB & 26.9 & - & $13,497.9$ & - & $1,675.3$ & - \\
AHJB1 & 10.5 & 60.9 & Nil & 100.0 & Nil & 100.0 \\
AHJB2 & 3.6 & 86.9 & Nil & 100.0 & Nil & 100.0 \\
DHJB & 24.5 & 7.8 & 593.9 & 95.6 & 212.8 & 87.3 \\
\hline
\end{tabular}

CAN, canavanine; $\mathrm{Hg}$, haemagglutinin; $\mathrm{TI}$, trypsin inhibitor; AHJB1, aqueous-heated Jack beans (beans soaked in distilled water for 48 hrs prior to $1 \mathrm{hr}$ cooking at $100^{\circ} \mathrm{C}$ ); AHJB2, aqueous-heated Jack beans (beans soaked in distilled water for $48 \mathrm{hrs}$ prior to $2 \mathrm{hrs}$ cooking at 1 hr interval); DHJB, dry-heated Jack beans (beans ovendried at $120^{\circ} \mathrm{C}$ for $30 \mathrm{~min}$.)

Results on performance characteristics of the growing broiler chicks are presented in Table 4. Feed intake was significantly $(p<0.05)$ improved in birds fed $15 \%$ AHJB2 than other Jack bean based diets. Intake of $\mathrm{DHJB}$ at $15 \%$ and $30 \%$ levels however gave significant $(p<0.05)$ reductions in the feed intake. No significant difference $(p>0.05)$ was obtained in feed intake between birds fed with 15\% AHJB1 and $30 \%$ AHJB2. Body weight gain and feed conversion also followed a similar trend to that of feed consumption. Moreover, birds fed $30 \%$ AHJ B2 gave lower body weight gain and feed conversion efficiency than birds fed 15\% AHJB2. Higher mortality were recorded in birds fed with diets contain in $15 \%$ and $30 \%$ DHJ B.

Data on hematological indices are shown in Table 5. Results showed that the red blood cells (RBC), hemoglobin $(\mathrm{Hb})$ and packed cell volume (PCV) of birds fed control diet and 15\% AHJ B2 were not significantly statistically. Other groups however had relatively lower RBC, PCV and $\mathrm{Hb}$ profiles in the blood. White blood cells (WBC) were significantly reduced $(p<0.05)$ in birds fed DHJ diets. 


\section{Utilization of processed Jack beans in broiler diet}

Table 4. Performance characteristics of broiler chickens fed aqueous-heated and dry-heated Jack beans

\begin{tabular}{lccccccc}
\hline & Control & $15 \%$ AHJB1 & $30 \%$ AHJB1 & $15 \%$ AHJB2 & $30 \%$ AHJB2 & $15 \%$ DHJB & $30 \%$ DHJB \\
\hline Feed Intake (g/week) & $224.7^{\mathrm{a}} \pm 2.94$ & $207.9^{\mathrm{b}} \pm 2.36$ & $194.6^{\mathrm{c}} \pm 2.17$ & $219.8^{\mathrm{a}} \pm 2.24$ & $212.1^{\mathrm{b}} \pm 2.01$ & $186.9^{\mathrm{d}} \pm 2.10$ & $185.5^{\mathrm{d}} \pm 2.03$ \\
Weight gain (g/week) & $146.3^{\mathrm{a}} \pm 1.78$ & $114.1^{\mathrm{c}} \pm 1.37$ & $103.6^{\mathrm{d}} \pm 1.21$ & $133.7^{\mathrm{b}} \pm 1.21$ & $121.1^{\mathrm{c}} \pm 1.22$ & $86.8^{\mathrm{e}} \pm 1.03$ & $80.8^{\mathrm{e}} \pm 1.04$ \\
Feed Conversion efficiency & $0.65^{\mathrm{a}} \pm 0.003$ & $0.55^{\mathrm{c}} \pm 0.002$ & $0.51^{\mathrm{d}} \pm 0.003$ & $0.61^{\mathrm{b}} \pm 0.005$ & $0.58 \mathrm{~b} \pm 0.03$ & $0.48^{\mathrm{d}} \pm 0.002$ & $0.43^{\mathrm{e}} \pm 0.001$ \\
Mortality (\%) & $2.01^{\mathrm{d}} \pm 0.02$ & $6.36^{\mathrm{b}} \pm 0.07$ & $6.98^{\mathrm{b}} \pm 0.06$ & $2.07 \mathrm{~d} \pm 0.03$ & $4.97 \mathrm{c} \pm 0.05$ & $8.96^{\mathrm{a}} \pm 0.04$ & $9.34^{\mathrm{a}} \pm 0.08$ \\
\hline
\end{tabular}

Means with different letters in the rows are significantly different $(p<0.05)$

Table 5. Hematological indices of birds fed aqueous-heated and dry-heated J ack beans

\begin{tabular}{llllllll}
\hline & Control & $15 \%$ AHJB1 & $30 \%$ AHJB1 & $15 \%$ AHJB2 & $30 \%$ AHJB2 & $15 \%$ DHJB & $30 \%$ DHJB \\
\hline RBC $(X 102 / \mu \mathrm{l}$ & $7.1 \mathrm{a} \pm 0.04$ & $6.5 \mathrm{~b} \pm 0.02$ & $6.0 \mathrm{c} \pm 0.02$ & $6.8 \mathrm{a} \pm 0.03$ & $6.3 \mathrm{~b} \pm 0.01$ & $5.8 \mathrm{c} \pm 0.03$ & $5.7 \mathrm{c} \pm 0.02$ \\
Hb $(\mathrm{g} / 100 \mathrm{ml})$ & $14.9 \mathrm{a} \pm 0.19$ & $13.3 \mathrm{~b} \pm 0.17$ & $12.4 \mathrm{c} \pm 0.16$ & $14.3 \mathrm{a} \pm 0.10$ & $12.7 \mathrm{c} \pm 0.15$ & $10.4 \mathrm{~d} \pm 0.14$ & $10.7 \mathrm{~d} \pm 0.13$ \\
PCV $(\%)$ & $43.3 \mathrm{a} \pm 0.69$ & $41.5 \mathrm{~b} \pm 0.42$ & $40.6 \mathrm{~b} \pm 0.48$ & $43.0 \mathrm{a} \pm 0.33$ & $41.9 \mathrm{~b} \pm 0.41$ & $37.8 \mathrm{c} \pm 0.38$ & $37.4 \mathrm{c} \pm 0.39$ \\
WBC $(\mathrm{X} 10 \% / \mu \mathrm{l})$ & $4.8 \mathrm{a} \pm 0.01$ & $4.2 \mathrm{~b} \pm 0.03$ & $4.1 \mathrm{bc} \pm 0.03$ & $4.3 \mathrm{~b} \pm 0.02$ & $4.4 \mathrm{~b} \pm 0.02$ & $3.9 \mathrm{c} \pm 0.01$ & $3.8 \mathrm{c} \pm 0.03$ \\
\hline
\end{tabular}

Means with different superscript in the same rows differed significantly ( $p<0.05)$; RBC, red blood cells; Hb, hemoglobin; PCV, packed cell volume; WBC, white blood cells

\section{Discussion}

The results obtained in this study showed that Jack bean had relatively high crude protein and crude fiber. These results are corroborating with the previous findings of Osuigwe et al. (2002); Osuigwe et al. (2006) and Ologhobo (1992). However, it is believed that the crude fibre content in the Jack beans is much higher than what is obtained in most grain legumes.

The canavanine, haemagglutinin and trypsin inhibitor contents obtained in the raw Jack bean in this study also corroborate the reports of Ologhobo et al. (1993) and Grant et al. (1983). The higher percentage reduction in the canavanine content of aqueous-heated Jack beans (AHJ B2) is similar to th findings of Udedibie (2003) that for Canavalia seed (ensiformis, gladiata or braziliensis) to be rendered nutritionally utilizable for humans and livestock, it should be cracked into pieces (4-6 pieces/seed), soaked in water for two days and then cooked for an hour or pressure cooked for 15 minutes.

The inactivation of the haemagglutinin and trypsin inhibitor of the two aqueous-heated samples (AHJB1 and AHJB2) supports the findings of Ologhobo et al. (1993) that moist heating inactivates the anti-nutritional factors. However, the residual amount of trypsin inhibitor obtained in dry-heated Jack beans (DHJ) is in support with the reports of Sabar et al. (1988). With the residual haemagglutinin and trypsin inhibitor in the dry-heated Jack beans ( $D H J B)$, there is a tendency for non-ruminant animals who do not have rumen to degrade the antinutritional factors to be negatively affected. This is because minute amounts of the toxic plant proteins in diets of chickens have been reported to cause serious metabolic disorders (Apata, 1990)

The significant increases in feed intake ( $\mathrm{FI})$, body weight gain (BWG) and feed conversion efficiency (FCE) of birds fed $15 \%$ AHJB2 in this study are a proof of very low level of toxicity in the grain legume. These increases were improvements over the findings of Ologhobo et al. (1993) who fed aqueous-heated Jack beans (Jack beans soaked in water for $24 \mathrm{hrs}$ and then cooked in water for $1 \mathrm{hr}$ only) to broiler chickens at $20 \%$ level. Moreover, the higher residual canavanine, haemagglutinin and trypsin inhibitor activities in $\mathrm{DHJ} B$ are suspected in this study to have contributed to the poor FI, BWG and FCE of the birds fed at $15 \%$ and $30 \%$ levels respectively. Michelangelli and Vargas (1994) reported that canavanine inhibits feed intake in non-ruminants.

Hematological indices revealed that broiler chickens fed $15 \%$ and $30 \%$ DHJ , and $30 \%$ AHJ B1 gave lower values of red blood cells (RBC), hemoglobin $(\mathrm{Hb})$, and packed cell volume (PCV) 
respectively. These are unusual variations in cellular constituents, and such have a tendency to affect the primary functions of the blood. According to Apata (1990), significant reductions in RBC, HB and PCV may be the result of toxic factors acting together to induce inhibition of hematopoiesis, hemolysis of RBC, and increase in the plasma volume. The decrease in white blood cells (WBC) especially in birds fed diets containing $15 \%$ and $30 \% \mathrm{DHJ}$, and $30 \% \mathrm{AHJB}$ reflects a decline in the production of blood cells for defensive mechanism against infections. This corroborates the findings of Agrawal and Mahajan (1980) that reduced WBC makes birds more susceptible to various physiological stresses resulting in diseases, greater mortality and poor growth.

\section{Conclusion}

In this study, the poor response indices in birds fed dry-heated Jack beans at $15 \%$ and $30 \%$ levels are an indication that dry heating is not an effective method of processing Jack beans. The high residual amount of canavanine in the dryheated Jack beans also suggest that long term consumption will create serious metabolic disorders and other undesirable anomalies. Moreover, the considerate loss of haemagglutinin, trypsin inhibitor and canavanine in the aqueousheated Jack beans, especially the batch soaked in water for $48 \mathrm{hrs}$ prior to $2 \mathrm{hrs}$ cooking at $1 \mathrm{hr}$ interval (AHJB2), reflected in the significant improvements in the response indices of birds when fed at $15 \%$ level. Moreover, intake of $\mathrm{AHJB} 2$ at $30 \%$ is considered too high for the growing broiler chicks in this study as the birds fed such diet performed a bit lower than those fed $15 \%$ AHJ B2.

\section{References}

Agrawal NK, Mahajan Cl (1980). Hematological changes due to vitamin $C$ deficiency in Channa punctatus block. Journal of Nutrition, 11: 2172-2182.

AOAC (1984). Official methods of analysis (14 ${ }^{\text {th }}$ ed.). Association of Official Analytical Chemists, Washington, DC.

Apata DF (1990). Biochemical, Nutritional and Toxicological assessment of some tropical seeds, Ph.D. Thesis, University of Ibadan, Nigeria.

Dacie JV, Lewis SM (1997). Practical hematology, $5^{\text {th }}$ ed. (London, Longman Group Ltd.), P. 21-68

D'Mello JPF, Acamovic I, Walker AG (1989). Nutritive value of Jack beans (Canavalia ensiformis) for young chicks: Effects of amino acid supplementation. Tropical Agriculture Trinidad, 66: 201-205

Eke CNU Asoegwu SN and Nwandikom Gl (2007). "Physical Properties of Jack bean (Canavalia ensiformis)" CIGR Ejournal Manuscript, 10: 7-14.

Grant G, Moore LJ, Mckenzie NH, Stewart JC, Pusztai A (1983). A survey of the nutritional and haemagglutinin properties of legumes seed generally available in the UK, British Journal of Nutrition, 50: 207214.

Leon AM, Caffin JP, Plassart M, Picard ML (1991). Effect of con A form Jack bean seeds on short term food intake regulation in chicks and lying hens. Animal Feed Science and Technology, 33: 118-126.

Michelangelli C, Vargas RE (1994). Influence of Canavanine on feed intake, plasma basic amino acid concentrations and kidney bean haemagglutinin activity in chicks, Journal of Nutrition, 124: 1081- 1087.

Natelson S, Bratton GR (1984). Canavanine assay of some alfalfa varieties. Practical procedure for canavanine preparation. Microchemical Journal, 29: 2643.

Obizobia IC, Obiano N (1998). The nutritive value of Jack bean (Canavalia ensiformis) Ecology and Food Nutrition, 21: 265-270.

Ologhobo AD (1992). Nutritive value of some tropical (West African) legumes for poultry. J ournal of Applied Animal Research, 2: 93104.

Ologhobo AD, Apata DE, Oyejide A (1993). utilization of raw Jack bean (Canavalia ensiformis) and Jack bean fraction in diets for broiler chicks. British Poultry Science, 34: 323-337.

Osuigwe DI, Al Obiekezie and JO Ogunji (2002). Preliminary evaluation of Jack bean (Canavalia ensiformis (L) DC) seed meal as a substitute for fishmeal in diets for Clariasgariepimus (Burchell 1822) In: 


\section{Utilization of processed Jack beans in broiler diet}

Challenges to Organic Farming and Sustainable Land Use in the Tropical and Subtropical.

Osuigwe DI, Al Obiekezie, GC Onuoha (2006). Effects of Jack bean seed meal on the intestinal mucosa of juvenile Heterobranelius longifilis. African Journal of Biotechnology, 5: 1294-1298.

Sridhar KR (2005). Biochemical and biological evaluation of an unconventional legume, Canavalia maritima of coastal sand dunes of India. Tropical and Subtropical Agroecosystems, 5: 1-14.

Steel RGD, Torrie JH (1980) Principles and procedures of statistics. New York, Mcgraw Hill. P. 107-109.

Udedibie ABI (2003). In search of food. FUTO and the nutritional challenge of Canavalia seeds. Inaugural Lecture Series 6. FUTO Press Limited. P. 21-31.

Udedibie ABI and Carlini CR (1998). Questions and answers to edibility problems of the Canavalia ensiformis seeds - A review: Animal Feed Science and Technology, 74: 95- 106.

Valdebouze P, Bergezone E, Gaborit T, DesortLaval J (1980). Content and distribution of trypsin inhibitors and haemagglutinin in some legume seeds. Canadian Journal of Plant Science, 60: 695-701.

Van Oort MG, Hamel RJ and Slager EA (1989). The trypsin inhibitor assay: Improvement of an existing method. Proceedings of workshop on anti-nutritional factors in legume seeds Pp 80-86 (Wegenigen, The Netherlands). 